\title{
TOLERANCE OF EGGPLANT (Solanum melongena L.) SEEDLINGS TO STRESS FACTORS
}

\author{
${ }^{1}$ Agnieszka Sękara, ${ }^{2}$ Renata Bączek-Kwinta, ${ }^{1}$ Andrzej Kalisz, ${ }^{1}$ Stanisław Cebula \\ ${ }^{1}$ Department of Vegetable and Medicinal Plants, Faculty of Horticulture, University of Agriculture in Krakow \\ 29-Listopada 54, 31-425 Kraków, Poland \\ ${ }^{2}$ Department of Plant Physiology, Faculty of Agriculture and Economics, University of Agriculture in Krakow \\ Podłużna 3, 30-239 Kraków, Poland \\ e-mail: a.sekara@ur.krakow.pl
}

Received: 16.12.2011

\section{Abstract}

The aim of the present study was to describe eggplant (Solanum melongena L.) tolerance to stress factors in the seedling stage as a basis for future studies on cross-tolerance to other stressors in subsequent stages of growth. After germination $\left(3\right.$ days $\left./ 26^{\circ} \mathrm{C}\right)$, 'Epic $\mathrm{F}_{1}$ ' seedlings were exposed to chilling stress $\left(3,6\right.$ and $\left.9^{\circ} \mathrm{C} \times 48 \mathrm{~h}^{-1}\right)$, heat stress $\left(35,40\right.$ and $45^{\circ} \mathrm{C}$

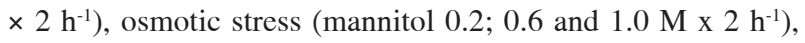
and oxidative stress $\left(\mathrm{H}_{2} \mathrm{O}_{2} 0.2 ; 0.4\right.$ and $\left.0.6 \mathrm{M} \times 2 \mathrm{~h}^{-1}\right)$. A linear measurement of seedling radicle growth, electrolyte leakage and external symptoms of radicle damage under the stress conditions, compared to the non-stressed control, were analyzed.

It was found that stressors in all experimental combinations caused a morphological and physiological response from eggplant seedlings. A significant reduction in linear growth of radicles, showed as an absolute length and as a percentage of the control, was found in the treatments exposed to chilling stress $\left(3\right.$ and $\left.6^{\circ} \mathrm{C}\right)$, heat stress $\left(35,40\right.$ and $\left.45^{\circ} \mathrm{C}\right)$, osmotic stress $(0.2,0.6$ and $1.0 \mathrm{M}$ mannitol) as well as oxidative stress (0.2, 0.4 and $0.6 \mathrm{M} \mathrm{H}_{2} \mathrm{O}_{2}$ ). The changes in seedling length as a result of stress factors did not always correspond with the changes in seedling mass. Electrolyte leakage in the treatments exposed to the following stressors: 3 and $6^{\circ} \mathrm{C}$ as well as $0.6 \mathrm{M} \mathrm{H}_{2} \mathrm{O}_{2}$, was significantly greater than that observed in control plants. Based on the obtained results and microscopic observations of radicle damage, the following stressors can be identified as those which cause a physiological response without severe damage: $9^{\circ} \mathrm{C} \times 48 \mathrm{~h}^{-1}$ (chilling stress), $35^{\circ} \mathrm{C} \times 2 \mathrm{~h}^{-1}$ (heat stress), $0.2 \mathrm{M}$ mannitol $\times 2 \mathrm{~h}^{-1}$ (osmoticum), and $\mathrm{H}_{2} \mathrm{O}_{2} 0.2 \mathrm{M} \times 2 \mathrm{~h}^{-1}$ (oxidation factor). We propose these stressors as a basis for future studies on plant acclimation and hardening to other stresses.

Key words: eggplant, seedlings, heat stress, chilling stress, osmotic stress, $\mathrm{H}_{2} \mathrm{O}_{2}$ stress

\section{INTRODUCTION}

Warm climate plant species like eggplant, grown in the temperate climate zone, are subjected to environmental stress which limits crop productivity, its quality, and post-harvest life. Detrimental environmental factors induce biochemical, physiological and cytological alterations, which could be reversible or irreversible, depending on their duration and intensity. The primary sensor of physical stress is a cell membrane, because a direct reduction in its liquidity is observed (Chinnus amy et al. 2006). Biochemical and physiological acclimation leads to cell membrane stiffening and reorganization of microfilaments which may be followed by activation of $\mathrm{Ca}^{2+}$ channels and an increased cytosolic $\mathrm{Ca}^{2+}$ level (Ö r v a r et al. 2000; $\mathrm{Ch}$ innusamy at al. 2006). The acclimation involves modification of plant calcium signalling to provide a "stress memory" (K night et al. 1996). As a strategy for protection against chilling, plants change the composition of the cell membrane lipid fraction towards increased membrane liquidity. For many species, an increase in the concentration of osmoregulators, mainly sugars, potassium ions, betaine, and proline, was observed during acclimation, in order to prevent the loss of water and stabilize macromolecules and biological membranes ( $\mathrm{Ch}$ e $\mathrm{n}$ and $\mathrm{Mur}$ a t a , 2008). Low temperature also causes oxidative stress, and in this case the plant protection strategy is to increase the synthesis of antioxidants (i.e. glutathione, ascorbate, carotenoids, flavonoids, polyphenols, tocopherols) and of specialized enzymes decomposing reactive oxygen species, i.e. superoxide dismutase, catalase, peroxidase, and the enzymes involved in 
glutahione metabolism (B a r t o s z , 1997; B ą c z e k - Kwinta et al. 2005; Bączek-Kwinta and Kościelniak, 2009).

A number of studies have shown the existence of cross-tolerance in plants. The exposure of a plant to one type of moderated stress can enhance the resistance to other multiple stresses ( $\mathrm{M} \mathrm{e} \mathrm{i}$ and S o n g ,2010). The seedling stage of development is characterized by the enhanced sensitivity to stress factors, concerned with the biochemical and physiological characteristic of meristematic tissues. The results of previous studies have revealed that treating seedlings with stress factors of sub-lethal intensity (hydrochloric acid, osmotic or heat stress) can increase tolerance to chilling (J e $\mathrm{n}$ nings and Saltveit, 1994; Mangrich and $\mathrm{S}$ alt ve it, 2000). Cucumber seedlings subjected to osmotic stress revealed increased tolerance to chilling (M a ngrich et al. 2006). Kang et al. (2005) have shown that the exposure of cucumber seedlings to osmotic and heat stress caused their increased tolerance to chilling. The ability to use the controlled stress in eggplant seedlings has only been considered in a few papers. G a o at al. $(2004 ; 2008)$ noticed a greater tolerance of grafted eggplant seedlings to low temperature $\left(4\right.$ and $\left.5^{\circ} \mathrm{C}\right)$, as compared to non-grafted ones, and revealed the key role of calcium ions in regulating the physiological mechanism of chilling tolerance. Q i o ng Q i u et al. (2005) explored the influence of cerium on seed germination and growth of eggplant seedlings under chilling stress $\left(10\right.$ and $\left.15^{\circ} \mathrm{C}\right)$. Ce decreased the symptoms of chilling, as a result of a change in cell membrane permeability, proline and sugar content and of increased hydrolase activity during germination. Kaizi and Chen (2005) compared the tolerance of seedlings of 14 eggplant cultivars to high temperature. Heat stress caused intensified electrolyte leakage and an increase in proline content. It seems that the leakage of electrolytes, reflecting the degree of damage to cell membranes, can be a good determinant of tolerance of eggplant seedlings. Although the temporary increase in permeability of the cell membranes under the stress conditions can be observed there, it may be one of the features acquired by the plants that helps to enhance their resistance to stress. The effect of this process is activation of the "stress memory" and cross resistance to another stressor.

The aim of the present investigations is to verify the tolerance of eggplant seedlings to selected stress factors on the basis of seedling radicle growth analysis and membrane status assayed as the electrolyte leakage. The intensity of stress factors, which are not lethal but cause a physiological response, is proposed. The results will provide the basis for future investigations on the enhancement of cross-tolerance of eggplant to stress factors during subsequent stages of growth.

\section{MATERIALS AND METHODS}

\section{Plant material and experimental design}

Eggplant (Solanum melongena $\mathrm{L}$.) 'Epic $\mathrm{F}_{1}$ ' seeds, sterilized with Thiuram (Organica-Azot, Jaworzno, Poland), were placed on Petri dishes with a layer of paper moistened with distilled water. After germination in an incubator ( 3 days $/ 26^{\circ} \mathrm{C}$ ), 30 uniform seedlings, with radicles initially $0.5-1.0 \mathrm{~mm}$ long, were selected as the material in the following experimental treatments:

1. Control - the exposure of seedlings to $26^{\circ} \mathrm{C}$ (optimal temperature) for $48 \mathrm{~h}$.

2. Chilling stress - the exposure of seedlings to 3,6 and $9^{\circ} \mathrm{C} \times 48 \mathrm{~h}^{-1}$, and $26^{\circ} \mathrm{C}$ for the next $48 \mathrm{~h}$.

3. Heat stress - the exposure of seedlings to 35,40 and $45^{\circ} \mathrm{C} \times 2 \mathrm{~h}^{-1}$, and $26^{\circ} \mathrm{C}$ for the next $48 \mathrm{~h}$.

4. Osmotic stress - the exposure of seedlings to mannitol in concentrations of $0.2 ; 0.6$ and $1.0 \mathrm{M} \times 2 \mathrm{~h}^{-1}$, and $26^{\circ} \mathrm{C}$ for the next $48 \mathrm{~h}$.

5. Oxidative stress - the exposure of seedlings to $\mathrm{H}_{2} \mathrm{O}_{2}$ in concentrations of $0.2 ; 0.4$ and $0.6 \mathrm{M} \times 2 \mathrm{~h}^{-1}$, and $26^{\circ} \mathrm{C}$ for the next $48 \mathrm{~h}$.

The experiment was conducted in darkness. All tests were conducted in three replications and repeated three times in 2010 (dates of beginning: April 05, May 10, June 16).

\section{Radicle length analysis}

The method modified by $\mathrm{R} \mathrm{ab}$ and $\mathrm{S}$ a ltve it (1996) was used for this purpose. The linear length measurement of the seedling radicle exposed to stress conditions, compared to the control, was analyzed. The measurements of the radicle length of each seedling were carried out (i) before stress factor application, (ii) after stress factor application and 48 hours at a temperature of $26^{\circ} \mathrm{C}$ - to investigate the recovery capacity of seedlings during rewarming, based on the difference between parameters after and before stress application. The measurements were made using the Image Tool for Windows 3.0 software, after registration of the image using a SteREO LUMAR V12 microscope (Carl Zeiss AG, Germany). The seedling mass was evaluated by direct mass measurement using an analytical scale (Sartorius, Germany).

\section{Electrolyte leakage (EL)}

The measurement of electrolyte leakage was based on the method of Markowski and Skrudlik (1995) and performed on seedlings taken after application of individual stress and an additional time period of 48 hours at a temperature of $26^{\circ} \mathrm{C}$. Plant material was washed with deionized water and then shaken for 24 hours in tubes with $15 \mathrm{~cm}^{3}$ of deionized water. The 
measurements of conductivity of the deionized water $\left(\mathrm{L}_{1}\right)$ and aquatic diffusate of the samples $(\mathrm{Lt})$ were made using a conductometer with automatic temperature compensation (Elmetron, Zabrze, Poland). Then, the samples were boiled at $100^{\circ} \mathrm{C}$ for $15 \mathrm{~min}$, shaken for $24 \mathrm{~h}$ and the assay was repeated to obtain the total content of electrolytes (Lk). The measurement of electrical conductivity of the deionized water was also repeated $\left(\mathrm{L}_{2}\right)$. Electrolyte leakage was calculated as a percentage of total electrolyte content according to the equation: $\mathrm{EL}=\left[\left(\mathrm{Lt}-\mathrm{L}_{1}\right) /\left(\mathrm{Lk}-\mathrm{L}_{2}\right)\right] \times 100 \%$.

\section{External symptoms of stress damage on seedlings}

The assessment of the external symptoms of damage after exposure to stress factors and additional time of 48 hours at a temperature of $26^{\circ} \mathrm{C}$ was made on the basis of observations of seedlings using a SteREO LUMAR V12 microscope (Carl Zeiss AG, Germany). The evaluation of damage caused by stress factors was assessed according to a grading system: 1 - severe injury, 2 more than $50 \%$ necrosis, 3 - partial injury with necrosis, 4 - partial injury, 5 - no injury.

\section{Statistical analysis}

The presented results are the means of 30 seedling measurements, in three experimental replications. All data obtained were subjected to one-way ANOVA, and the differentiation of the means was compared by the Tukey test at $\mathrm{P} \leq 0.05$. In all the figures, the data marked with the same letter do not differ significantly and the variability of data is shown as error bars representing standard errors of the means.

\section{RESULTS}

The stressors in all experimental combinations caused a morphological and physiological response from eggplant seedlings. A significant reduction in linear growth of radicles, showed as an absolute length and as a percentage of the control, was found in the treatments exposed to chilling stress $\left(3\right.$ and $\left.6^{\circ} \mathrm{C}\right)$, heat stress $\left(35,40\right.$ and $\left.45^{\circ} \mathrm{C}\right)$, and osmotic stress $(0.2,0.6$ and $1.0 \mathrm{M}$ mannitol) as well as oxidative stress (0.2, 0.4 and $0.6 \mathrm{M} \mathrm{H}_{2} \mathrm{O}_{2}$ ) - Figs 1 and 2. Exposure of seedlings to $9^{\circ} \mathrm{C}$ caused a significant increase in radicle length by about $13 \%$ compared to the control (Fig. $1 \mathrm{~A})$. The action of $3^{\circ} \mathrm{C}$ caused the greatest reduction in radicle growth by about $50 \%$ compared to the control. Figure 1B shows that in the heat stress treatments a similar reduction of radicle growth was observed in seedlings exposed to 40 and $45^{\circ} \mathrm{C}(42-47 \%$ of the control). A temperature of $35^{\circ} \mathrm{C}$ caused a $36 \%$ reduction in radicle growth. Seedlings treated with increased solutions of mannitol and $\mathrm{H}_{2} \mathrm{O}_{2}$ showed a com- mensurate reduction in radicle growth (Fig. 2A, 2B). Exposure of seedlings to $0.2,0.6$ and $1.0 \mathrm{M}$ mannitol solutions resulted in a decrease in radicle growth by 43,51 , and $79 \%$, respectively. Seedlings treated with $0.2,0.4$, and $0.6 \mathrm{M} \mathrm{H}_{2} \mathrm{O}_{2}$ exhibited a 36,43 , and $52 \%$ reduction in linear growth of the radicle in comparison to the control. It should be stated that the linear measurement of seedling radicle growth under stress conditions seemed to be a good parameter for the description of the response of eggplant seedlings to stress factors.

The changes in seedling length resulting from the stress response did not always correspond with changes in seedling mass. Exposure of seedlings to 3 and $6^{\circ} \mathrm{C}$, and $1.0 \mathrm{M}$ mannitol significantly reduced their mass by about 20, 40 and $20 \%$ respectively, as compared to the control (Figs 1C, 2C). A statistically significant increase in seedling mass was observed as a result of $0.2 \mathrm{M}$ mannitol treatment (Fig. 2C). The mass of seedlings exposed to $9,35,40$ and $45^{\circ} \mathrm{C}, 0.6 \mathrm{M}$ mannitol, 0.2, 0.4 and $0.6 \mathrm{M} \mathrm{H}_{2} \mathrm{O}_{2}$ was comparable to the control (Figs 1C, 1D, 2C, 2D).

The electrolyte leakage in the treatments with seedlings exposed to the following stressors: 3 and $6^{\circ} \mathrm{C}$ as well as $0.6 \mathrm{M} \mathrm{H}_{2} \mathrm{O}_{2}$, was significantly greater compared with the control (Figs 1E, 2F). There were no statistical differences in electrolyte leakage between the treatments exposed to different levels of heat stress (Fig. 1F). Seedlings treated with 0.2 and $1.0 \mathrm{M}$ mannitol resulted in significantly lower electrolyte leakage from the tissues of stressed seedlings as compared to the control (Fig. 2E).

The microscopic observations of seedling radicle damage were performed in order to describe the external symptoms of a plant's reaction to the stressors. The characteristic injury caused by the lowest of the applied temperatures $\left(3\right.$ and $\left.6^{\circ} \mathrm{C}\right)$ caused up to $50 \%$ necrosis (Figs 1G, 3A, 3B). Chilling with a temperature of $9^{\circ} \mathrm{C}$ resulted in a slight visual injury to the seedling radicles (Figs 1G, 3C). Heat stress (35 and $40^{\circ} \mathrm{C}$ ) caused only a slight - but statistically significant when compared to the control - injury to the seedlings (Figs 1H, 3D, 3E). The result of $45^{\circ} \mathrm{C}$ treatment was partial damage to the radicles; namely up to $50 \%$ necrosis (Figs $1 \mathrm{H}, 3 \mathrm{~F}$ ). The treatment of seedlings with $1.0 \mathrm{M}$ mannitol resulted in the most severe damage among all treatments investigated (Figs 2G, 3I). Mannitol, applied in concentrations of 0.2 and $0.6 \mathrm{M}$, caused a slight visual damage to the seedling radicles (Figs 2G, 3G, 3H). The hydrogen peroxide in concentrations of 0.4 and $0.6 \mathrm{M}$ caused partial injury to the seedling radicles (Figs $2 \mathrm{H}, 3 \mathrm{~K}, 3 \mathrm{~L}$ ). In a concentration of $0.2 \mathrm{M}$, the visual injury was significantly smaller (Figs 2H, 3J) . 


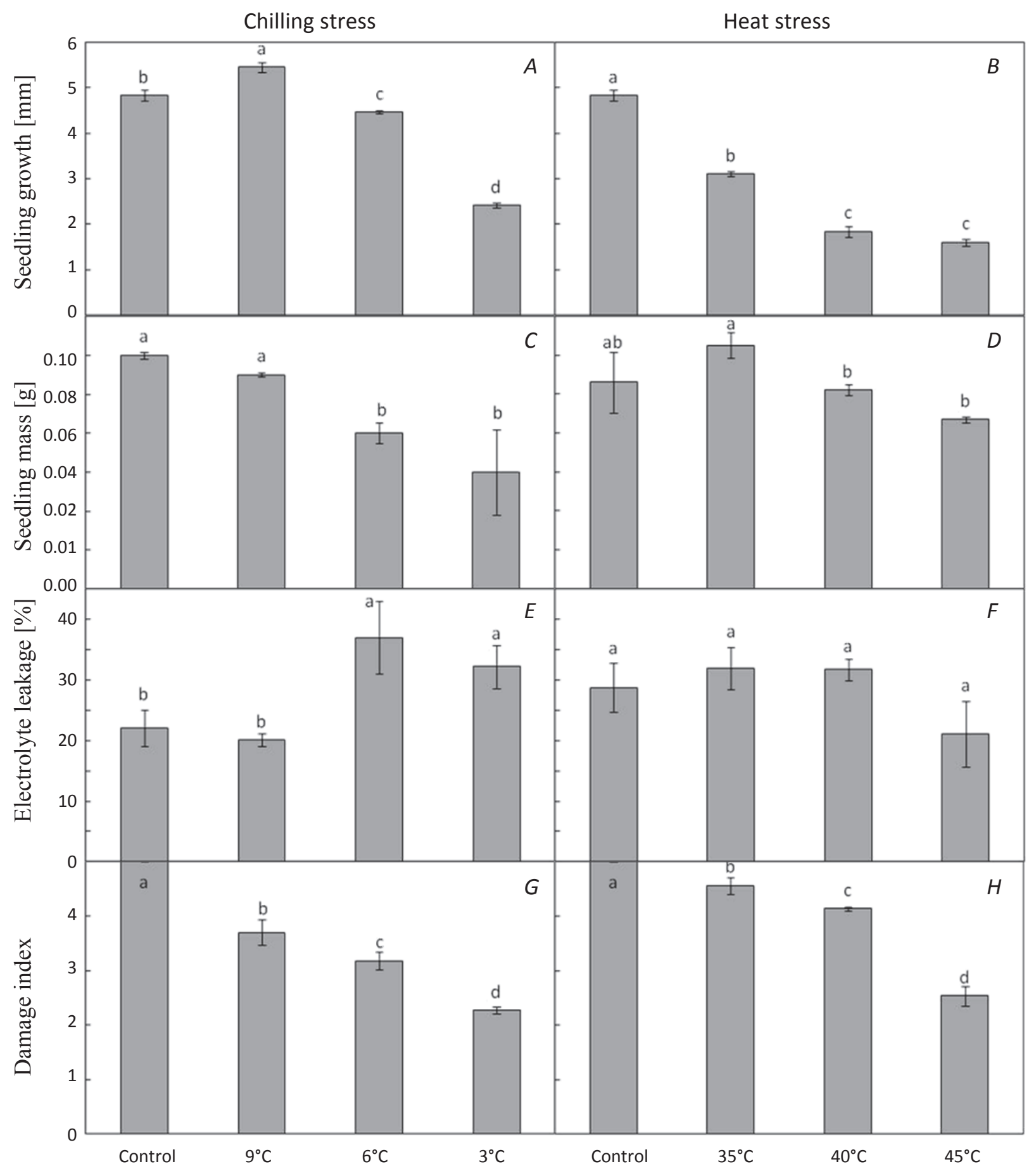

Fig. 1. The effect of chilling stress $\left(9,6,3^{\circ} \mathrm{C} \times 48 \mathrm{~h}^{-1}\right.$ and subsequent $26^{\circ} \mathrm{C} \times 48 \mathrm{~h}^{-1}$ treatment $)$ and heat stress $\left(35,40,45^{\circ} \mathrm{C} \times 2 \mathrm{~h}^{-1}\right.$ and subsequent $26^{\circ} \mathrm{C} \times 48 \mathrm{~h}^{-1}$ treatment) on eggplant seedlings growth (A, B), mass (C, D), electrolyte leakage (E, F), damage index: 1 - severe injury, 2 - more than $50 \%$ necrosis, 3 - partial injury with necrosis, 4 - partial injury, 5 - no injury (G, H). Means marked with the same letter do not differ significantly (Tukey's test, $\mathrm{P} \leq 0.05$ ). 


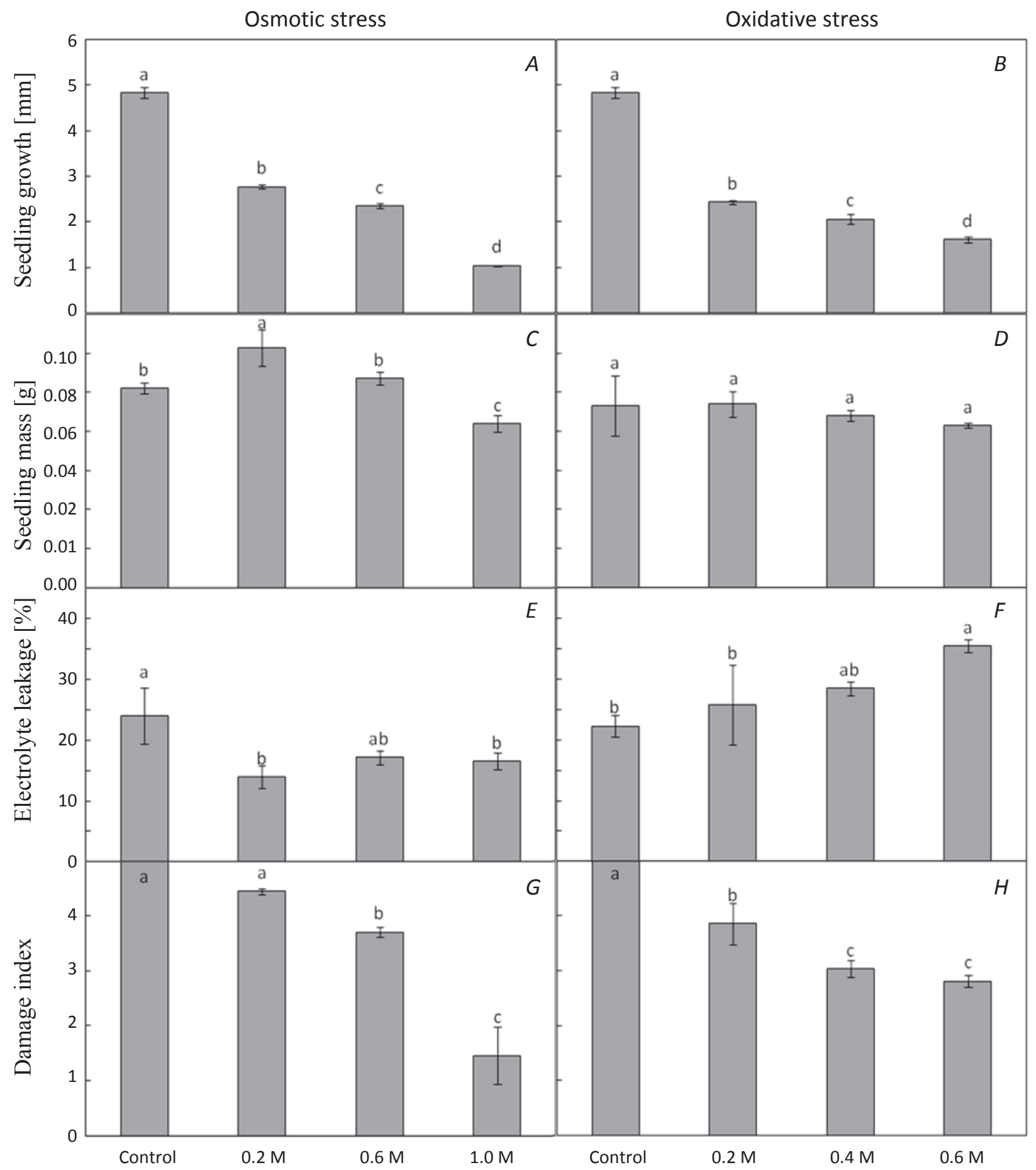

Fig. 2. The effect of osmotic stress (mannitol $0.2,0.6,1.0 \mathrm{M} \times 2 \mathrm{~h}^{-1}$ and subsequent $26^{\circ} \mathrm{C} \times 48 \mathrm{~h}^{-1}$ treatment) and oxidative stress $\left(\mathrm{H}_{2} \mathrm{O}_{2} 0.2,0.4,0.6 \mathrm{M} \times 2 \mathrm{~h}^{-1}\right.$ and subsequent $26^{\circ} \mathrm{C} \times 48 \mathrm{~h}^{-1}$ treatment) on eggplant seedling growth (A, B), mass (C, D), electrolyte leakage (E, F), damage index: 1 - severe injury, 2 - more than $50 \%$ necrosis, 3 - partial injury with necrosis, 4 - partial injury, 5 - no injury $(\mathrm{G}, \mathrm{H})$. Means marked with the same letter do not differ significantly (Tukey’s test, $\mathrm{P} \leq 0.05$ ). 

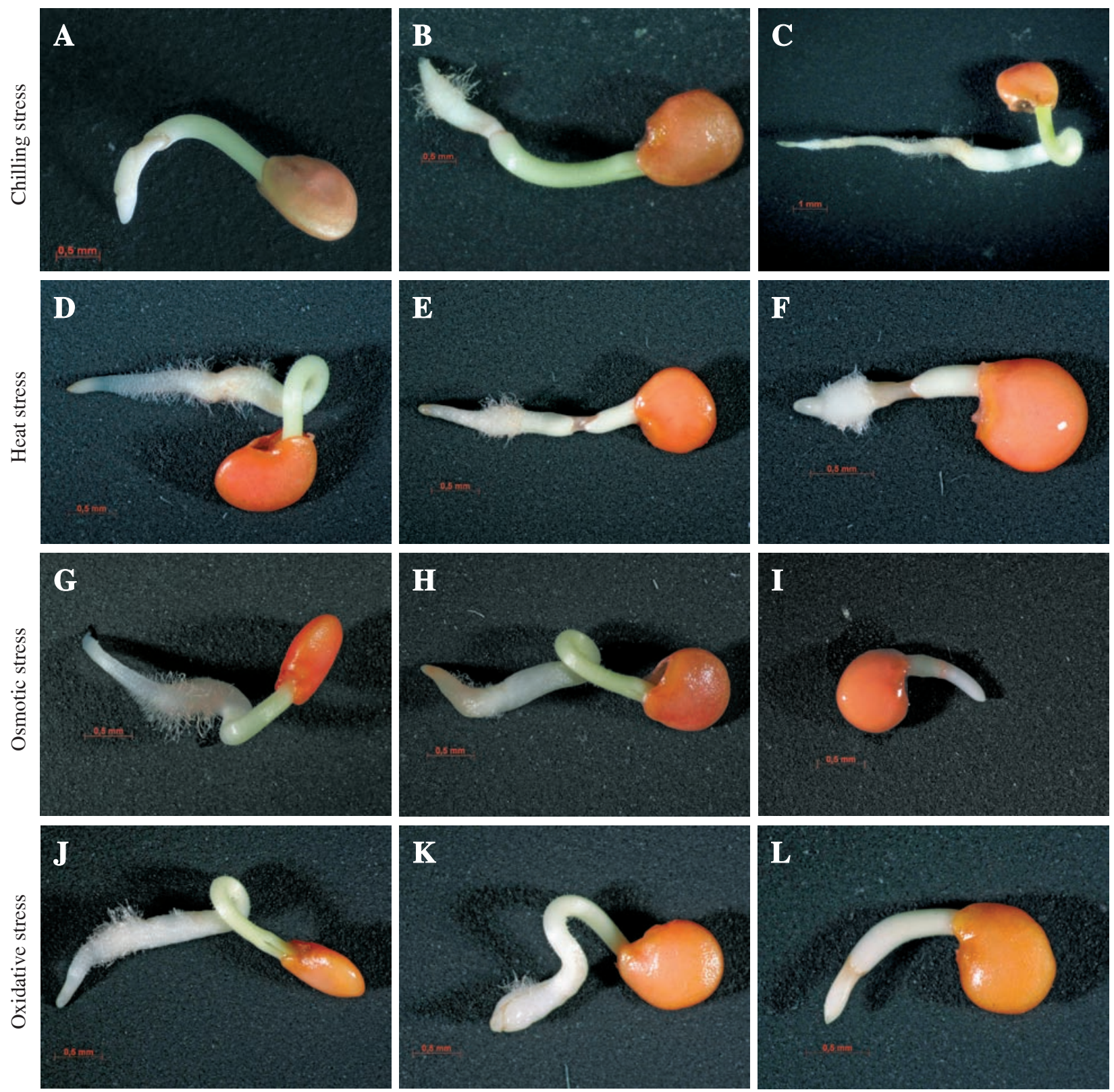

Fig. 3. Visual damage and growth disruption caused by chilling stress - temperature $3^{\circ} \mathrm{C}(\mathrm{A}), 6^{\circ} \mathrm{C}(\mathrm{B})$, and $9^{\circ} \mathrm{C}(\mathrm{C}) \times 48 \mathrm{~h}^{-1}$ and subsequent $26^{\circ} \mathrm{C} \times 48 \mathrm{~h}^{-1}$ treatment; heat stress - temperature $35^{\circ} \mathrm{C}(\mathrm{D}), 40^{\circ} \mathrm{C}(\mathrm{E})$, and $45^{\circ} \mathrm{C}(\mathrm{F}) \times 2 \mathrm{~h}^{-1}$ and subsequent $26^{\circ} \mathrm{C} \times 48 \mathrm{~h}^{-1}$ treatment; osmotic stress - mannitol 0.2 M (G), $0.6 \mathrm{M}(\mathrm{H})$ and $1.0 \mathrm{M}(\mathrm{I}) \times 2 \mathrm{~h}^{-1}$ and subsequent $26^{\circ} \mathrm{C} \times 48 \mathrm{~h}^{-1}$ treatment; and oxidative stress - hydrogen peroxide $0.2 \mathrm{M}(\mathrm{J}), 0.4 \mathrm{M}(\mathrm{K})$ and $0.6 \mathrm{M}(\mathrm{L}) \times 2 \mathrm{~h}^{-1}$ and subsequent $26^{\circ} \mathrm{C} \times 48 \mathrm{~h}^{-1}$ treatment. Photos representative to $\mathrm{n}=25$.

\section{DISCUSSION}

The studies concerning the stress sensitivity of plants are often performed on seedling tissues or whole seedlings, because the response of young plants to stress is rapid and can be easily monitored. $\mathrm{Ka} \mathrm{izi}$ and $\mathrm{Ch}$ e $\mathrm{n}$ (2005) screened the tolerance of seedlings of 14 eggplant varieties to heat stress. The authors proposed that, among others, electrolyte leakage might be suitable for selecting heat tolerant eggplant genotypes in breeding programmes.
The increase of electrolyte leakage in the case of seedlings exposed to 3 and $6^{\circ} \mathrm{C}$, as well as $0.6 \mathrm{M}$ $\mathrm{H}_{2} \mathrm{O}_{2}$, suggests considerable changes in cell membrane permeability of these plantlets. S a l t v e it (2002) proved the reduction in radicle growth of rice exposed to chilling $\left(5^{\circ} \mathrm{C}\right)$. The presented results confirm a significant reduction in linear growth of eggplant radicles, shown as an absolute length and as a percentage of the control, in the seedlings subjected to chilling stress ( 3 and $6^{\circ} \mathrm{C}$ ). It is interesting that treatment with $9^{\circ} \mathrm{C}$ 
caused a significant increase in radicle length (about $13 \%$ ), but its mass was comparable to the control. There was no impact of $9^{\circ} \mathrm{C}$ on electrolyte leakage. Thus, moderate chilling of eggplant seedlings with $9^{\circ} \mathrm{C}$ can be a possible way to enhance its tolerance to stress factors in subsequent growth stages.

$\mathrm{Ku} \mathrm{m}$ a r et al. (2010) suggested that under heat stress the growth inhibition depended on the genotype and temperature of treatment. S a to et al. (2001) pointed out that heat shock can protect rice seedlings against chilling injury. E s e $\mathrm{m}$ in e et al. (2010) observed that very high temperatures may provoke cellular injury and subsequent cell death, but moderately high temperatures can provoke considerable damage, after a long-term exposure. According to the cited authors, direct injuries include protein denaturation and increased fluidity of membrane lipids. Indirect injuries, due to a lower heat level, include inactivation of enzymes, inhibition of protein synthesis, protein degradation and loss of membrane integrity. In the present study, no significant differences were found in electrolyte leakage between the seedlings exposed to heat stress. The temperatures of 40 and $45^{\circ} \mathrm{C}$ dramatically reduced seedling growth and caused visual damage. Interestingly, as a result of a temperature of $35^{\circ} \mathrm{C}$, we obtained a significant increase in seedling mass (although radicle growth was not altered); therefore, it could be possible to study eggplant cross-tolerance to stress after exposure of seedlings to this temperature.

Many studies have used mannitol as an osmotic component generating osmotic stress ( $\mathrm{S}$ a de ghi a n and Yavari, 2004). Sadeghian and Yavari (2004) applied 0.0, 0.2 and 0.3 M mannitol to assess the rate of seed germination and early seedling growth in sugar beet under water deficit stress conditions. Seedling growth and germination rates severely declined at the highest concentration of mannitol. In the present study, it was interesting that the exposure to 0.2 and $1.0 \mathrm{M}$ mannitol resulted in significantly lower electrolyte leakage from the stressed seedlings, compared to the control. When analyzed, the external symptoms of damage displayed no differences between control and mannitol-treated seedlings, therefore a low level of tissue damage was confirmed in the seedlings in this part of the experiment. Seedlings exposed to $0.2 \mathrm{M}$ mannitol were characterized by a higher mass compared to the control, but the radicle elongation was reduced. Therefore, when applied in a concentration of $0.2 \mathrm{M}$, mannitol can be an effective factor enhancing the tolerance of eggplant to stress factors in subsequent growth stages. For example, $\mathrm{K}$ a n g et al. (2005) showed that exposure to osmotic $(0.6 \mathrm{M}$ mannitol $)$ or heat $\left(2 \mathrm{~min}\right.$ at $\left.45^{\circ} \mathrm{C}\right)$ stress enhanced chilling tolerance of cucumber seedlings.

Mittle r at al. (2004) underlined the dual role for reactive oxygen species (i.e. $\mathrm{H}_{2} \mathrm{O}_{2}$ ) in plant biology, as toxic byproducts of aerobic metabolism and key regulators of growth, development and defence pathways. Also $\mathrm{W}$ a n and $\mathrm{Liu}$ (2008) emphasized that $\mathrm{H}_{2} \mathrm{O}_{2}$ plays a dual role in plants as the toxic by-product of normal cell metabolism and as a regulatory molecule in stress perception and signal transduction. Excessive $\mathrm{H}_{2} \mathrm{O}_{2}$ generation resulting in an oxidative stress in plants was observed as a result of chilling, salinity, heavy metals, drought and other biotic and abiotic stress factors (B a c zek-Kwinta, 2005; Ślesak et al. 2007). On the contrary, exogenous $\mathrm{H}_{2} \mathrm{O}_{2}$ can enhance the tolerance of plants to salt stress ( $\mathrm{Li}$ et al. 2010), chilling (L i n and S a l t ve it , 2005; Feng et al. 2008), drought (Q i u et al. 2010), heat (W a h i d et al. 2008). In this study, exposure of eggplant seedlings to $0.2 \mathrm{M}$ $\mathrm{H}_{2} \mathrm{O}_{2}$ resulted in a significant decrease in radicle linear growth, but it had no significant influence on its mass and cell membrane status. Visual damage was also slight in this case. A strong correlation between the effect of $\mathrm{H}_{2} \mathrm{O}_{2}$ on plant growth and the decrease in ABA was observed by B a r b a - E s p in et al. (2010). Lin and S altveit (2005) tested the hypothesis that moderate oxidative stress offers protection against chilling injury of mungbean seedlings. They also showed that chilling inhibits the subsequent radicle growth and indicated a possible role of moderate stress in inducing partial tolerance to the chilling of that species.

\section{CONCLUSIONS}

The presented results provide a new concept for eggplant seedling development under stress environments. Exposure of seedlings to stress factors in the manner proposed can be a way to increase eggplant tolerance to subsequent environmental stressors during ontogenesis. The proposed stressors triggered the physiological response of eggplant seedlings without significant injury, so we can postulate that the results provide a foundation for future investigations on cross-tolerance or subsequent tolerance of eggplant to stress factors and possibilities to enhance its tolerance to environmental stresses.

\section{Acknowledgements}

This work was supported by grant No. N N310 440638 of the Ministry of Science and Higher Education, Poland, in 2010-2013.

\section{REFERENCES}

Barba-Espin G., Diaz-Vivancos P., ClementeMoreno M.J., Albacete A., Faize L., Faize M., Pérez-Alfocea F., Hernández J.A., 2010. Interaction between hydrogen peroxide and plant hormones during germination and 
the early growth of pea seedlings. Plant Cell Environ. 33(6):981-994.

Bartosz G., 1997. Oxidative stress in plants. Acta Physiol. Plant. 19(1):47-64.

B ączek-Kwinta R., Kościelniak J., 2009. The mitigating role of experimental factors in seedling injury and chill-dependent depression of catalase activity in maize leaves. Biol. Plant. 53(2):278-284.

Bączek-Kwinta R., Niewiadomska E., Miszalski Z., 2005. Physiological role of reactive oxygen species in chill-sensitive plants. Phyton. 45:25-37.

Chen T.H.H., Murata N., 2008. Glycinebetaine: an effective protectant against abiotic stress in plants. Trends Plant Sci. 13(9):499-505.

Chinnusamy V., Jianhua Z., Jian-Kang Z., 2006. Gene regulation during cold acclimation in plants. Physiol. Plant. 126(1):52--6.

Esemine J., Ammar S., Bouzid S., 2010. Impact of heat stress on germination and growth in higher plants: physiological, biochemical and molecular repercussions and mechanisms of defence. J. Biol. Sci. 10(6):565-572.

Feng H., Li X., Duan J., Li H., Liang H., 2008. Chilling tolerance of wheat seedlings is related to an enhanced alternative respiratory pathway. Crop Sci. 48:2381-2388

Gao Q.H., Chen G., Han L., Lin H., 2004. Calcium influence on chilling resistance of grafting eggplant seedlings. J. Plant Nutr. 27(8):1327-1339.

Gao Q.H., Xu K., Wang X.F., Wu Y., 2008. Effect of grafting on cold tolerance in eggplant seedlings. Acta Hort. (ISHS) 771:167-174.

Jennings P., Saltveit M.E., 1994. Temperature and chemical shocks induce chilling tolerance in germinating Cucumis sativus (cv. Poinsett 76) seeds. Physiol. Plant. 91:703-707.

Kaizi J.I.A., Chen G., 2005 Tolerance of different eggplant varieties at seedling stage to high temperature stress. Chinese J. Ecol. 24(04):398-401.

Kang H.M., Park K.W., Saltveit M.E., 2005. Chilling tolerance of cucumber (Cucumis sativus) seedling radicles is affected by radicle length, seedling vigor, and induced osmotic- and heat-shock proteins. Physiol. Plant. 124:485-492.

Knight H., Trewavas A.J., Knight M.R., 1996. Cold calcium signaling in Arabidopsis involves two cellular pools and a change in calcium signature after cold acclimation. Plant Cell, 8:489-503.

Kumar S., Gupta D., Nayyar H., 2010. Comparative response of maize and rice genotypes to heat stress: status of oxidative stress and antioxidants. Acta Physiol. Plant. doi: 10.1007/s11738-011-0806-9.

Li J.-T., Qiu Z.-B., Zhang X.-W., Wang L.-S., 2010. Exogenous hydrogen peroxide can enhance tolerance of wheat seedlings to salt stress. Acta Physiol. Plant. 33(3):835-842.
Lin W.C., Saltveit M.E., 2005. Oxidative stress and chilling injury of mungbean seedlings. Acta Hort. (ISHS) 682:1293-1296.

Mangrich M.E., Martinez-Font R.T., Saltveit M.E., 2006. Radicle length and osmotic stress affect the chilling sensitivity of cucumber radicles. Crop Sci. 46:398-403.

Mangrich M.E., Saltveit M.E., 2000. Effect of chilling, heat shock, and vigor on the growth of cucumber (Cucumis sativus) radicles. Physiol. Plant 109:137-142.

Markowski A., Skrudlik G., 1995. Electrolyte leakage, ATP content in leaves and intensity of net photosynthesis in maize seedlings at permanent or different daily exposure to low temperature. J. Agron. Crop Sci. 175:109-117.

Mei Y., Song S., 2010. Response to temperature stress of reactive oxygen species scavenging enzymes in the cross-tolerance of barley seed germination. Biomed. Biotechnol. 11(12):965-972.

Mittler R., Vanderauwera S., Gollery M., Van Breusegem F., 2004. Reactive oxygen gene network of plants. Trends in Plant Sci. 9(10):490-498.

Örvar B.L., Sangwan V., Omann F., Dhinds a R.S ., 2000. Early steps in cold sensing by plant cells: the role of actin cytoskeleton and membrane fluidity. Plant J. 23:785-794.

QiongQiu Q., Liu L., Jing Y., ZhuJun Z., 2005. Physiological effects of cerium on seed germination and seedling growth in eggplant under chilling stress. Acta Hort. Sin. 32(4):710-712.

Qiu Z., Shi J., Zhang M., Yu R., Yue M., 2010. Effect of hydrogen peroxide on $\mathrm{CO}_{2}$ laser pretreatment induced drought tolerance in wheat seedlings. Chinese J. Lasers 37(8):2170-2176.

Rab A., Saltveit M.E., 1996. Differential chilling sensitivity in cucumber (Cucumis sativus) seedlings. Physiol. Plant. 96:375-382.

Sadeghian S.Y., Yavari N., 2004. Effect of water deficit stress on germination and early seedling growth in Sugar Beet. J. Agron. Crop Sci. 190:138-142.

S altveit M.E., 2002. Heat shocks increase the chilling tolerance of rice (Oryza sativa) seedling radicles. Agric. Food Chem. 50(11):3232-3235.

Sato Y., Murakami T., Funatsuki H., Matsuba S., Saruyama H., Tanida M., 2001. Heat-shock mediated APX gene expression ad protection against chilling injury in rice seedlings. J. Exp. Bot. 52(354):145-151.

Ślesak I., Libik M., Karpińska B., Karpiński S., Miszalski Z ., 2007. The role of hydrogen peroxide in regulation of plant metabolism and cellular signaling in response to environmental stresses. Acta Biochimica Pol. 54(1):39-50.

Wahid A., Sehar S., Perveen M., Gelani S., Basra S.M.A., Farooq M., 2008. Seed pretreatment with hydrogen peroxide improves heat tolerance 
in maize at germination and seedling growth stages. Seed Sci. Technol. 36(3):633-645.

Wan X.-Y., Liu J.-Y., 2008. Comparative proteomics analysis reveals an intimate protein network provoked by hydrogen peroxide stress in rice seedling leaves. Mol Cell Proteomics, 7:1469-1488.

\section{Tolerancja siewek oberżyny (Solanum melongena L.) na czynniki stresowe}

\section{Streszczenie}

Celem przeprowadzonych badań była analiza tolerancji oberżyny (Solanum melongena L.) w stadium siewek na czynniki stresowe. Po skiełkowaniu (3 dni $/ 26^{\circ} \mathrm{C}$ ), siewki oberżyny 'Epic $\mathrm{F}_{1}$ ' poddano działaniu stresu chłodowego $\left(3,6\right.$ i $\left.9^{\circ} \mathrm{C} \times 48 \mathrm{~h}^{-1}\right)$, cieplnego $\left(35,40 \mathrm{i} 45^{\circ} \mathrm{C} \times 2 \mathrm{~h}^{-1}\right.$ ), osmotycznego (mannitol 0,2 ; 0,6 i $\left.1,0 \mathrm{M} \times 2 \mathrm{~h}^{-1}\right)$, i oksydacyjnego $\left(\mathrm{H}_{2} \mathrm{O}_{2} 0,2\right.$; 0,4 i $\left.0,6 \mathrm{M} \times 2 \mathrm{~h}^{-1}\right)$. Analizowano wzrost elongacyjny korzonka zarodkowego, wyciek elektrolitów oraz zewnętrzne objawy uszkodzeń korzonka zarodkowego w warunkach stresu, w porównaniu do nie stresowanej kontroli. Stwierdzono, że stresory we wszystkich eksperymentalnych kombinacjach wywołały morfologiczną i fizjologiczną reakcję siewek oberżyny. Istotny spadek przyrostu liniowego korzonków zarodkowych, wykazany w postaci ich bezwzględnej długości, jak i procentowo w stosunku do kontroli, stwierdzono w obiekcie eksponowanym na stres chłodowy $\left(3\right.$ i $\left.6^{\circ} \mathrm{C}\right)$, cieplny $\left(35,40\right.$ i $\left.45^{\circ} \mathrm{C}\right)$, osmotyczny $(0,2 ; 0,6$ i $1,0 \mathrm{M}$ mannitol) oraz oksydacyjny $(0,2 ; 0,4$ i $0,6 \mathrm{M} \mathrm{H}_{2} \mathrm{O}_{2}$ ). Zmiany długości korzonka zarodkowego siewek pod wpływem czynników stresowych nie zawsze odpowiadały zmianom ich masy. Wyciek elektrolitów w obiektach eksponowanych na następujące czynniki stresowe: 3 i $6^{\circ} \mathrm{C}$ oraz $0,6 \mathrm{M} \mathrm{H}_{2} \mathrm{O}_{2}$ był istotnie większy, niż obserwowany w obiekcie kontrolnym. Na podstawie otrzymanych wyników oraz mikroskopowych obserwacji zewnętrznych uszkodzeń powierzchni korzonka zarodkowego, wytypowano następujące stresowy, które wywołują odpowiedź fizjologiczną ze strony siewek oberżyny bez poważnych uszkodzeń tkanek: $9^{\circ} \mathrm{C} \times 48 \mathrm{~h}^{-1}$ (stres chłodowy), $35^{\circ} \mathrm{C} \times 2 \mathrm{~h}^{-1}$ (stres cieplny), $0.2 \mathrm{M}$ mannitol $\times 2 \mathrm{~h}^{-1}$ (stres osmotyczny), i $\mathrm{H}_{2} \mathrm{O}_{2} 0.2 \mathrm{M} \times 2 \mathrm{~h}^{-1}$ (stres oksydacyjny). Zaproponowano te czynniki stresowe jako bazowe do dalszych badań nad zwiększeniem tolerancji oberżyny na inne stresory działające w kolejnych fazach wzrostu i rozwoju ontogenetycznego. 